\title{
Evaluation of Rajma Bean Landraces for Growth, Yield and Quality under Low Altitude Condition of Nagaland
}

\author{
A. Thirugnanavel ${ }^{1 *}$, Bidyut C. Deka ${ }^{2}$, Rakesh Kumar ${ }^{3}$, Lily Rangnamei ${ }^{4}$, \\ Megokhona Meyase ${ }^{4}$ and Kollam Rabi ${ }^{5}$
}

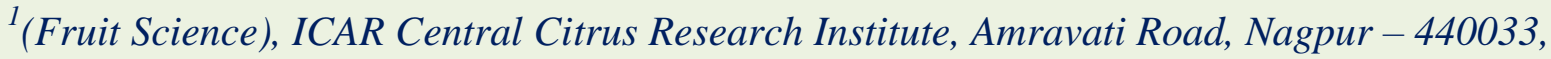
Maharashtra, India

${ }^{2}$ ICAR Agricultural Technology Application Research Institute, Umiam, Barapani-793103, Meghalaya, India

${ }^{3}$ (Agronomy), ICAR Research Complex for Eastern Region, Patna - 800014, Bihar, India

${ }^{4}$ SMS (Horticulture), ${ }^{5}$ SMS (Plant Breeding) KVK, ICAR Research Complex for NEH Region, Nagaland Centre, Jharnapani - 797106, Nagaland, India

*Corresponding author

A B S T R A C T

\begin{tabular}{|l|}
\hline K e y w or d s \\
Rajma, Landraces, \\
Growth, Yield, \\
Quality \\
\hline Article Info \\
\hline $\begin{array}{l}\text { Accepted: } \\
\text { 20 September } 2018 \\
\text { Available Online: } \\
10 \text { October } 2018\end{array}$ \\
\hline
\end{tabular}

An experiment was conducted during 2013-15 at Research Farm, ICAR Research Complex for NEH Region, Nagaland Centre, Jharnapani, Nagaland to evaluate thirty two landraces of rajma bean for the growth, yield and quality under low altitude conditions of Nagaland. The experiment was laid out in randomized complete block design with three replications. Eighteen traits viz., growth, yield related components and four quality parameters were recorded. Significant variations were observed for all the traits studied among the landraces evaluated. The results revealed that the line RCN 11 and RCN 20 performed better under lower altitude conditions of Nagaland. The RCN 11 and RCN 20 have recorded the highest seed yield of $63.8 \mathrm{~g} /$ plant. The maximum 100 -seed weight was recorded by RCN $11(60.0 \mathrm{~g})$ and RCN 20 (56.2 g). The highest yield of 1766.1 and 1766.8 $\mathrm{kg} / \mathrm{ha}$ was recorded by RCN 11 and RCN 20 respectively. RCN 6 recorded highest protein content of $20.1 \%$ and this line also registered $49.3 \mathrm{~g} / \mathrm{plant}$ seed yield and $1256.4 \mathrm{~kg} / \mathrm{ha}$ yields.

\section{Introduction}

Northeast India, a mega diversity hotspot, is rich in genetic diversity (Deka et al., 2012) which has the wide range of agricultural crops, among them rajma is one of the important crops. Nagaland, a North eastern State of India has rich cultural and crop genetic diversity. Rajma bean (Phaseolus vulgaris L.), a nutrient-rich legume, is widely cultivated pulse in jhum fields next to rice bean (Das et al., 2016). It is cultivated as pure crop and as a mixed crop along with upland paddy and maize along with other crops in jhum fields. It 
occupies a prime position in kitchen garden and backyards. Rajma vernacularly called as Kholar, Ajoxa, Khetsuthi, and Ajokha serves as a vital source of plant protein in the diet of ethnic people of Nagaland. The dry beans are rich in protein, starch, and fibre (Beebe et al., 2000) and rich in minerals and vitamins (Boughton et al., 2003) and called as poor man's meat. This nutrient-rich legume, an integral part of food in Nagaland, is mainly cultivated at higher altitudes particularly Kiphere, Tuensang, Zunheboto, and Kohima districts. It is regarded as a cash crop by jhumias and they grow several landraces (Verma et al., 2014). The people consume rajma both as pulse and vegetable in the form of boiled or fried food.

Genetic diversity of rajma beans is rich in Nagaland and several indigenous landraces have been cultivated by farmers. Rajma has been mainly cultivated twice during FebruaryMarch and August. These landraces vary in morphology, growth pattern, seed size, shape, texture, yield and taste. Selection of landraces differed with farmers based on their preference. Many farmers cultivated the landraces based on taste, thus resulted in poor yield (Verma et al., 2014). These vast genetic pools of rajma bean are under threat due to urbanization, declining soil fertility, change in rainfall pattern, the introduction of new crops, etc. Lack of knowledge on genetic diversity and its characters affects the improvement programme. Hence, this study aims to collect and evaluate the rajma landraces to identify the high yielding and nutrient-rich lines.

\section{Materials and Methods}

Thirty-two indigenous landraces of rajma beans collected from different districts of Nagaland were evaluated at Research Farm, ICAR Research Complex for NEH Region, Nagaland centre, Jharnapani during 2013-14 and 2014-15. The experimental field is situated at $25^{\circ} 45^{\prime} 24^{\prime \prime} \mathrm{N}$ latitude and 93'50'26" E longitude; and an altitude of $281 \mathrm{~m} \mathrm{msl}$. The experiment was laid out in Randomized Block Design with three replications. The rajma landraces were planted at a spacing of $60 \times 60 \mathrm{~cm}$ and the standard package of the practices was followed. The observations viz., plant height $(\mathrm{cm})$, inflorescence length $(\mathrm{cm})$, no of flowers per inflorescence, no of pods per inflorescence, pod length $(\mathrm{cm})$, pod width $(\mathrm{cm})$, pedicel length $(\mathrm{cm})$, pod beak length $(\mathrm{cm})$, seed length $(\mathrm{cm})$, seed width $(\mathrm{cm})$, number of locules per pod, no of seeds per pod, seed weight (g), 100 seed weight $(\mathrm{g})$, no of pods per plant, no seeds per plant, yield per plant (g), estimated yield per hectare (t/ha) were recorded. The observations were recorded in 10 plants in each replication and ten pods were randomly selected for observing pod related characters.

The quality parameters like nitrogen, phosphorous, potassium and crude protein were estimated. The dry beans were ground using Willey Mill and sieved through 60 mesh size. The bean powders were stored in air tight containers until use and used for analysis. The total nitrogen, phosphorous and potassium were calculated as per A.O.A.C (1980). The crude protein content was calculated by multiplying the $\mathrm{N}$ value with constant 6.25. The data were analyzed for analysis of variance using HAU OPSTAT statistical software packages (Sheoran et al., 1988).

\section{Results and Discussion}

The results from the study revealed that significant positive variations were observed for the characters evaluated. The data on morphological characters presented in the table 1 revealed that the maximum plant height of $253.1 \mathrm{~cm}$ was recorded by RCN 30, which was closely followed by RCN 2 (204.0 $\mathrm{cm})$. The minimum plant height was recorded by $\mathrm{RCN} 24(27.3 \mathrm{~cm})$, which was closely 
followed by RCN $4(33.9 \mathrm{~cm})$ and RCN 16 $(35.7 \mathrm{~cm})$. The maximum inflorescence length of $7.8 \mathrm{~cm}$ was registered by RCN 9 and the minimum of $4.1 \mathrm{~cm}$ was registered by $\mathrm{RCN}$ 24. The maximum number of 4.8 flowers per inflorescence was recorded by RCN 12 and the minimum of 3.0 flowers per inflorescence was recorded by RCN 23. The no. of pods/inflorescence is very much important criteria that affect the yield of the plant. The maximum no. of pods per inflorescence was recorded by RCN 20 (3.7) and the minimum no. of pods per inflorescence was recorded by RCN 23 (1.0). Pod length is an important character which decides the market value for vegetable purpose and the no. of seeds per pod for pulse purpose. The maximum pod length of $17.1 \mathrm{~cm}$ was recorded by RCN 20 and the minimum pod length of $7.0 \mathrm{~cm}$ was recorded by $\mathrm{RCN} 16$. The maximum pod width was registered by RCN 1 and $\mathrm{RCN} 10(1.5 \mathrm{~cm})$ and the minimum pod width was registered by RCN 23, RCN 28, and RCN 32 (0.9 cm). Similarly, the maximum pedicel length was registered by RCN $23(1.1 \mathrm{~cm})$ and minimum was registered by $\mathrm{RCN} 5(0.4 \mathrm{~cm})$. The maximum pod beak length was registered in RCN $3(1.9 \mathrm{~cm})$ and it was lowest in RCN 26 $(0.4 \mathrm{~cm})$. Similar results for variation in growth characters were recorded by Anjanappa et al., (2000), Durusum (2007) and Sofi et al., (2011). The vast difference between the landraces was observed and it may be due to genetic characters, growing conditions, and inherent nature of the landraces where they originated from different parent sources by open pollination. The diversity found for these characters revealed that Nagaland is rich in broad genetic diversity of rajma bean.

Significant variation was observed among the landraces studied for yield and yield related traits and the data were presented in table 2 . The seed length, seed width, individual seed weight and test weight are important parameters that affect the yield directly. In this present study, the maximum seed length of 2.1 $\mathrm{cm}$ of was recorded by RCN 24 and the minimum seed length of $0.9 \mathrm{~cm}$ was recorded by RCN 25 and RCN 32. RCN 29 and RCN 30 registered the maximum seed width $(1.2$ $\mathrm{cm}$ ), whereas RCN 7, RCN 15 and RCN 25 registered the minimum seed width $(0.6 \mathrm{~cm})$. The highest single seed weight of $0.60 \mathrm{~g}$ was recorded by RCN 11 and the lowest seed weight of $0.19 \mathrm{~g}$ was recorded by RCN 15 . The highest 100-seed weight was recorded by RCN $11(60.0 \mathrm{~g})$ and the lowest 100-seed weight was recorded by RCN 15 (18.8 g).

The maximum no. of locules per pod (7.8) and seeds per pod (7.0) were recorded by RCN 24 . The minimum of 4.6 locules per pod was recorded by RCN 30 and the minimum of 3.9 seeds per pod was recorded by RCN 20. The no. of pods per plant and no. of seeds per plant ultimately decide the yield of the plant. The data on these two parameters revealed that the highest no. of pods per plant was recorded by RCN 5 (41.4) which was closely followed by $\mathrm{RCN} 12$ (38) and RCN 20 (36.9).

The lowest of 8.4 and 8.7 pods per plant was recorded by RCN 25 and RCN 30 respectively. RCN 5 recorded 202.5 seeds per plant and RCN 30 recorded the lowest of 36.5 seeds per plant and RCN 3 recorded 46.3 seeds per plant. Variations in no. o pods per plant, seeds per plant, 100 seed weight among different common bean varieties were observed by Adelson et al., (2000), Fegaria et al., (2010) and Sofi et al., (2011). Inherent genetics of the landraces and the growing environment may influence the genetic variation among the landraces.

Ultimately yield is the main aim of any breeding programme or farmer's point of view. The yield per plant varied from 15.1$63.8 \mathrm{~g} / \mathrm{plant}$. The maximum yield of 63.8 g/plant was recorded by RCN 11 and RCN 20. 
Table.1 Evaluation of growth and morphological characters of rajma bean landraces

\begin{tabular}{|c|c|c|c|c|c|c|c|c|}
\hline Lines & $\begin{array}{l}\text { Plant } \\
\text { height } \\
(\mathrm{cm})\end{array}$ & $\begin{array}{l}\text { Infloresce } \\
\text { nce length } \\
\text { (cm) }\end{array}$ & $\begin{array}{l}\text { No of flowers/ } \\
\text { inflorescence }\end{array}$ & $\begin{array}{l}\text { No of pods/ } \\
\text { inflorescence }\end{array}$ & $\begin{array}{l}\text { Pod } \\
\text { length } \\
(\mathrm{cm})\end{array}$ & $\begin{array}{l}\text { Pod } \\
\text { width } \\
\text { (cm) }\end{array}$ & $\begin{array}{l}\text { Pedicel } \\
\text { length } \\
(\mathrm{cm})\end{array}$ & $\begin{array}{l}\text { Pod } \\
\text { beak } \\
\text { length } \\
(\mathrm{cm})\end{array}$ \\
\hline RCN 1 & 181.7 & 6.6 & 4.2 & 2.1 & 12.2 & 1.5 & 0.8 & 0.9 \\
\hline RCN 2 & 204.0 & 7.3 & 3.9 & 2.4 & 16.0 & 1.2 & 0.9 & 0.9 \\
\hline RCN 3 & 101.5 & 7.1 & 4.0 & 2.8 & 11.4 & 1.4 & 0.9 & 1.9 \\
\hline $\mathrm{RCN} 4$ & 33.9 & 7.6 & 4.1 & 2.1 & 13.7 & 1.3 & 0.5 & 1.2 \\
\hline RCN 5 & 179.6 & 6.5 & 4.0 & 2.0 & 11.4 & 1.2 & 0.4 & 1.0 \\
\hline RCN 6 & 48.9 & 6.9 & 3.9 & 2.0 & 12.3 & 1.2 & 0.9 & 1.4 \\
\hline RCN 7 & 137.2 & 6.1 & 3.6 & 1.3 & 10.1 & 1.0 & 0.7 & 1.1 \\
\hline RCN 8 & 117.3 & 6.8 & 4.4 & 2.9 & 10.7 & 1.3 & 0.8 & 1.2 \\
\hline RCN 9 & 72.5 & 7.8 & 4.5 & 2.0 & 11.4 & 1.4 & 0.8 & 1.3 \\
\hline RCN 10 & 52.0 & 6.5 & 4.1 & 2.7 & 12.3 & 1.5 & 0.7 & 1.5 \\
\hline RCN 11 & 75.2 & 6.4 & 4.5 & 2.9 & 13.9 & 1.2 & 1.0 & 1.7 \\
\hline RCN 12 & 78.7 & 7.0 & 4.8 & 1.9 & 10.3 & 1.3 & 0.8 & 0.7 \\
\hline RCN 13 & 92.0 & 5.4 & 3.8 & 2.8 & 9.9 & 1.4 & 0.9 & 0.8 \\
\hline RCN 14 & 107.2 & 6.2 & 4.5 & 1.9 & 13.8 & 1.2 & 1.0 & 1.1 \\
\hline RCN 15 & 51.1 & 5.2 & 3.1 & 2.1 & 16.3 & 1.1 & 0.7 & 0.7 \\
\hline RCN 16 & 35.7 & 4.6 & 3.1 & 2.8 & 7.0 & 1.0 & 1.0 & 1.1 \\
\hline RCN 17 & 50.0 & 6.5 & 3.5 & 2.8 & 11.5 & 1.4 & 1.0 & 1.1 \\
\hline RCN 18 & 132.9 & 5.0 & 3.1 & 2.9 & 14.0 & 1.3 & 0.8 & 1.2 \\
\hline RCN 19 & 141.8 & 7.4 & 3.4 & 2.0 & 11.5 & 1.1 & 1.0 & 0.9 \\
\hline RCN 20 & 82.6 & 5.4 & 4.0 & 3.7 & 17.1 & 1.3 & 1.0 & 1.2 \\
\hline RCN 21 & 128.5 & 7.4 & 3.7 & 2.5 & 12.8 & 1.4 & 0.9 & 1.1 \\
\hline RCN 22 & 76.6 & 7.0 & 3.6 & 2.1 & 12.5 & 1.2 & 1.0 & 1.1 \\
\hline RCN 23 & 118.9 & 5.1 & 3.0 & 1.0 & 11.1 & 0.9 & 1.1 & 1.1 \\
\hline RCN 24 & 27.3 & 4.1 & 3.3 & 2.0 & 15.4 & 1.0 & 0.6 & 0.7 \\
\hline$\overline{R C N} 25$ & 161.0 & 6.5 & 4.3 & 1.9 & 15.1 & 1.2 & 0.7 & 0.9 \\
\hline RCN 26 & 133.6 & 5.1 & 3.9 & 2.0 & 12.5 & 1.1 & 0.5 & 0.4 \\
\hline RCN 27 & 118.5 & 5.9 & 4.2 & 2.1 & 14.1 & 1.0 & 0.6 & 0.8 \\
\hline RCN 28 & 127.1 & 5.5 & 4.1 & 2.1 & 9.1 & 0.9 & 0.5 & 0.6 \\
\hline RCN 29 & 104.9 & 5.3 & 3.8 & 2.9 & 13.7 & 1.1 & 0.7 & 0.5 \\
\hline RCN 30 & 253.1 & 6.4 & 4.1 & 2.0 & 10.4 & 1.3 & 0.9 & 1.1 \\
\hline RCN 31 & 115.2 & 6.3 & 3.4 & 2.5 & 10.9 & 1.1 & 0.7 & 0.6 \\
\hline RCN 32 & 157.4 & 6.1 & 4.3 & 2.0 & 10.4 & 0.9 & 0.6 & 0.7 \\
\hline $\begin{array}{l}\text { CD } \\
(0.05)\end{array}$ & 12.92 & 0.17 & 0.28 & 0.28 & 0.22 & 0.09 & 0.10 & 0.09 \\
\hline $\mathrm{CV}$ & 7.22 & 1.71 & 4.44 & 7.40 & 1.11 & 4.75 & 7.62 & 5.70 \\
\hline
\end{tabular}


Table.2 Evaluation of yield and yield related characters of rajma bean landraces

\begin{tabular}{|c|c|c|c|c|c|c|c|c|c|c|}
\hline Lines & $\begin{array}{l}\text { Seed } \\
\text { lengt } \\
\text { h } \\
(\mathrm{cm})\end{array}$ & $\begin{array}{l}\text { Seed } \\
\text { width } \\
(\mathrm{cm})\end{array}$ & $\begin{array}{l}100 \\
\text { seed } \\
\text { weight } \\
(\mathrm{g})\end{array}$ & $\begin{array}{l}\text { No of } \\
\text { locule } \\
\text { s / pod }\end{array}$ & $\begin{array}{l}\text { No of } \\
\text { seeds / } \\
\text { pod }\end{array}$ & $\begin{array}{l}\text { Single } \\
\text { seed } \\
\text { weight } \\
\text { (g) }\end{array}$ & $\begin{array}{l}\text { No of } \\
\text { pods } \\
\text { /plant }\end{array}$ & $\begin{array}{l}\text { No of } \\
\text { seeds / } \\
\text { plant }\end{array}$ & $\begin{array}{l}\text { Yield/ } \\
\text { plant } \\
\text { (g) }\end{array}$ & $\begin{array}{l}\text { Yield } \\
\text { (t/ha) }\end{array}$ \\
\hline RCN 1 & 1.7 & 0.7 & 42.1 & 5.3 & 4.8 & 0.42 & 17.2 & 82.6 & 34.7 & 960.5 \\
\hline RCN 2 & 1.4 & 0.8 & 27.8 & 6.9 & 5.8 & 0.27 & 12.8 & 74.2 & 20.0 & 555.2 \\
\hline RCN 3 & 1.2 & 0.8 & 47.6 & 5.5 & 5.2 & 0.47 & 8.9 & 46.3 & 21.8 & 602.5 \\
\hline$\overline{\mathrm{RCN}} 4$ & 1.2 & 0.9 & 42 & 6.4 & 6.2 & 0.42 & 12.8 & 79.4 & 33.3 & 923.3 \\
\hline RCN 5 & 1.1 & 0.9 & 29.5 & 6.5 & 6.1 & 0.29 & 41.4 & 202.5 & 58.7 & 1626.7 \\
\hline RCN 6 & 1.5 & 0.8 & 52.5 & 6.0 & 4.9 & 0.52 & 18.6 & 87.1 & 45.3 & 1254.6 \\
\hline RCN 7 & 1 & 0.6 & 32.5 & 6.8 & 6.2 & 0.33 & 11.7 & 72.5 & 23.9 & 663.1 \\
\hline RCN 8 & 1.3 & 0.8 & 45.2 & 6.1 & 5.8 & 0.45 & 17.5 & 96.5 & 43.4 & 1202.9 \\
\hline RCN 9 & 1.6 & 0.8 & 55.9 & 6.3 & 5.8 & 0.56 & 16.3 & 94.5 & 52.9 & 1466.5 \\
\hline RCN 10 & 1.4 & 0.8 & 46.2 & 6.8 & 6.2 & 0.46 & 15.9 & 98.6 & 45.3 & 1256.1 \\
\hline RCN 11 & 1.7 & 0.9 & 60 & 7.0 & 6.2 & 0.6 & 36.5 & 106.3 & 63.8 & 1766.7 \\
\hline RCN 12 & 1.1 & 1 & 37.9 & 6.3 & 5.7 & 0.38 & 38.0 & 160.6 & 61.0 & 1690.5 \\
\hline RCN 13 & 1 & 0.7 & 28 & 5.0 & 4.6 & 0.28 & 18.2 & 83.7 & 23.4 & 649.3 \\
\hline RCN 14 & 1.3 & 0.9 & 37.4 & 7.4 & 6.7 & 0.37 & 12.5 & 83.8 & 31.0 & 858.4 \\
\hline RCN 15 & 1.1 & 0.6 & 18.8 & 7.7 & 6.9 & 0.19 & 11.5 & 79.4 & 15.1 & 417.6 \\
\hline RCN 16 & 1 & 0.7 & 36 & 5.1 & 4.7 & 0.36 & 11.5 & 54.1 & 19.5 & 539.0 \\
\hline RCN 17 & 1.7 & 1 & 53.9 & 6.2 & 5.4 & 0.54 & 9.7 & 52.4 & 28.3 & 783.5 \\
\hline RCN 18 & 1.6 & 0.8 & 33.7 & 6.0 & 5.0 & 0.34 & 16.5 & 82.5 & 28.1 & 777.0 \\
\hline RCN 19 & 1.1 & 0.9 & 30.8 & 5.1 & 4.2 & 0.31 & 15.0 & 63.0 & 19.5 & 541.0 \\
\hline RCN 20 & 1.5 & 1 & 56.2 & 5.1 & 3.9 & 0.56 & 36.9 & 113.9 & 63.8 & 1766.8 \\
\hline RCN 21 & 1.4 & 0.9 & 55.1 & 6.7 & 6.1 & 0.55 & 16.5 & 90.7 & 49.9 & 1381.8 \\
\hline RCN 22 & 1.6 & 0.9 & 28.3 & 5.6 & 4.6 & 0.28 & 13.2 & 60.7 & 17.0 & 470.9 \\
\hline RCN 23 & 1.1 & 0.8 & 26.5 & 7.6 & 6.2 & 0.26 & 14.5 & 89.9 & 23.4 & 647.5 \\
\hline RCN 24 & 2.1 & 0.9 & 44.5 & 7.8 & 7.0 & 0.44 & 9.0 & 63.0 & 27.7 & 767.8 \\
\hline RCN 25 & 0.9 & 0.6 & 39.7 & 6.4 & 6.0 & 0.37 & 8.4 & 50.4 & 18.6 & 516.5 \\
\hline RCN 26 & 1.1 & 0.7 & 40.5 & 6.9 & 6.0 & 0.41 & 14.1 & 84.6 & 34.7 & 960.8 \\
\hline RCN 27 & 1.1 & 0.8 & 33.5 & 6.9 & 6.1 & 0.34 & 10.2 & 62.2 & 21.2 & 586.0 \\
\hline RCN 28 & 1.4 & 0.7 & 36.7 & 6.4 & 6.1 & 0.37 & 19.0 & 115.9 & 42.9 & 1187.9 \\
\hline RCN 29 & 1.6 & 1.2 & 33.3 & 7.2 & 6.2 & 0.33 & 12.2 & 75.6 & 25.0 & 691.4 \\
\hline RCN 30 & 1.6 & 1.2 & 52.3 & 4.6 & 4.2 & 0.52 & 8.7 & 36.5 & 19.0 & 526.3 \\
\hline RCN 31 & 1.3 & 0.9 & 24.5 & 7.0 & 6.1 & 0.25 & 25.2 & 153.7 & 38.4 & 1064.5 \\
\hline RCN 32 & 0.9 & 0.6 & 36.6 & 6.9 & 6.6 & 0.36 & 21.7 & 123.2 & 44.4 & 1228.6 \\
\hline $\begin{array}{l}\text { CD } \\
(0.05)\end{array}$ & 0.11 & 0.09 & 7.97 & 0.16 & 0.12 & 0.01 & 0.67 & 3.47 & 1.56 & 42.73 \\
\hline C.V & 4.80 & 6.73 & 12.51 & 1.55 & 1.28 & 1.60 & 2.31 & 2.39 & 2.76 & 2.74 \\
\hline
\end{tabular}


Table.3 Evaluation of quality parameters of rajma bean landraces

\begin{tabular}{|c|c|c|c|c|}
\hline Lines & $\begin{array}{c}\text { Nitrogen } \\
(\%)\end{array}$ & $\begin{array}{c}\text { Phosphorus } \\
(\mathbf{m g} / \mathbf{1 0 0 g})\end{array}$ & $\begin{array}{c}\text { Potassium } \\
(\mathbf{m g} / \mathbf{1 0 0 g})\end{array}$ & $\begin{array}{c}\text { Crude protein } \\
(\%)\end{array}$ \\
\hline RCN 1 & 2.94 & 0.21 & 0.89 & 18.4 \\
\hline RCN 2 & 2.86 & 0.21 & 0.92 & 17.9 \\
\hline RCN 3 & 3.14 & 0.24 & 1.05 & 19.6 \\
\hline RCN 4 & 2.13 & 0.21 & 0.66 & 13.3 \\
\hline RCN 5 & 2.69 & 0.18 & 0.44 & 16.8 \\
\hline RCN 6 & 3.22 & 0.18 & 0.29 & 20.1 \\
\hline RCN 7 & 2.60 & 0.19 & 0.49 & 16.3 \\
\hline RCN 8 & 2.38 & 0.21 & 1.01 & 14.9 \\
\hline RCN 9 & 2.83 & 0.19 & 1.54 & 17.7 \\
\hline RCN 10 & 2.72 & 0.28 & 0.99 & 17.0 \\
\hline RCN 11 & 2.74 & 0.26 & 0.96 & 17.2 \\
\hline RCN 12 & 2.21 & 0.11 & 1.31 & 13.8 \\
\hline RCN 13 & 3.05 & 0.19 & 0.78 & 19.1 \\
\hline RCN 14 & 2.63 & 0.24 & 0.85 & 16.5 \\
\hline RCN 15 & 2.69 & 0.24 & 0.89 & 16.8 \\
\hline RCN 16 & 2.63 & 0.20 & 0.79 & 16.5 \\
\hline RCN 17 & 2.91 & 0.17 & 0.45 & 18.2 \\
\hline RCN 18 & 2.88 & 0.23 & 1.02 & 18.0 \\
\hline RCN 19 & 2.63 & 0.20 & 0.83 & 16.5 \\
\hline RCN 20 & 2.63 & 0.22 & 1.05 & 16.5 \\
\hline RCN 21 & 2.18 & 0.24 & 1.32 & 13.7 \\
\hline RCN 22 & 2.58 & 0.20 & 0.83 & 16.1 \\
\hline RCN 23 & 2.72 & 0.19 & 0.90 & 17.0 \\
\hline RCN 24 & 2.69 & 0.22 & 0.98 & 16.8 \\
\hline RCN 25 & 3.11 & 0.23 & 0.84 & 19.4 \\
\hline RCN 26 & 3.02 & 0.23 & 0.86 & 18.9 \\
\hline RCN 27 & 2.77 & 0.24 & 0.90 & 17.3 \\
\hline RCN 28 & 2.91 & 0.23 & 1.03 & 18.2 \\
\hline RCN 29 & 3.08 & 0.30 & 0.83 & 19.3 \\
\hline RCN 30 & 2.80 & 0.25 & 1.18 & 17.5 \\
\hline RCN 31 & 2.72 & 0.23 & 1.09 & 17.0 \\
\hline RCN 32 & 2.77 & 0.23 & 1.06 & 17.3 \\
\hline CD (0.05) & 0.08 & 0.02 & 0.05 & 0.45 \\
\hline CN & 1.75 & 4.47 & 3.15 & 1.78 \\
\hline & & & & \\
\hline
\end{tabular}

The minimum yield of $15.1 \mathrm{~g} / \mathrm{plant}$ was recorded by RCN 15 which was closely followed by RCN $22(17.0 \mathrm{~g} / \mathrm{plant})$. The yield per hectare was calculated based on per plant yield and plant population her hectare. The highest yield of $1766.8 \mathrm{~kg} / \mathrm{ha}$ and 1766.1 $\mathrm{kg} / \mathrm{ha}$ was recorded by RCN 20 and RCN 11 respectively. The lowest yield of $417.6 \mathrm{~kg}$ was recorded by RCN 15 . Similarly the genetic variation in grain yield and yield 
related traits were reported by Anjanappa et al., (2000), Fegaria et al., (2010), Kamaludin (2011), Sofi et al., (2011) and Jyothi Devi et al., (2015) in common bean. The yield is of prime most importance in any of the crop improvement programme. Vast diversity was found among the landraces evaluated for yield. The performance of the landraces at low altitude is less and still, some of the lines performed better with higher yield. The RCN 11 and RCN 20 were performed better at lower altitude.

The data on quality traits were presented in the table 3 and the results revealed that significant positive variations were observed for the traits studied. The RCN 6 recorded maximum nitrogen $(3.22 \%)$, maximum crude protein $(20.1 \%)$ and minimum potassium content $(0.29 \mathrm{mg} / 100 \mathrm{~g})$. The line $\mathrm{RCN} 4$ recorded the minimum nitrogen content $(2.13$ $\%)$. The maximum phosphorous content was recorded by RCN 29 (0.30 mg/100g) and the minimum phosphorous was recorded by RCN $12(0.11 \mathrm{mg} / 100 \mathrm{~g})$. The maximum potassium content was recorded by RCN 9. The variation in the quality traits among the landraces may be due to inherent genetic nature of the landraces. The greater level of genetic diversity for nutrient composition of common beans was earlier reported by Moraghan and Grafton, (1997), Pardes et al., (2009) and Guzmán-Maldonado et al., (2000).

From this study, it was concluded that the high level of genetic diversity was observed among the landraces for growth, yield related traits, yield and quality. Based the results, the lines RCN 11 and RCN 20 were performed better in terms of seed weight, 100 seed weight, seed yield per plant, and yield per hectare. These lines have the potential of giving $1766 \mathrm{~kg}$ per hectare. The line RCN 6 recorded high crude protein content of $20.1 \%$ with the yield of $1256 \mathrm{~kg}$ per hectare. Hence these lines can be used for further evaluation at different locations and can be used for genetic improvement of rajma beans for high yield and high protein contents.

\section{Acknowledgement}

The authours are highly grateful to Director, ICAR Research Complex for NEH Region, Umiam, Barapani, Meghalaya for financial assistance and technical guidance.

\section{References}

Adelson Paulo Araújo, Marcelo Grandi Teixeira and Dejair Lopes de Almeida 2000. Growth and yield of common bean cultivars at two soil phosphorus levels under biological nitrogen fixation. Pesq. Agropec. Bras., Brasilia. 35(4): 809-817.

Anjanappa, M., N. S. Reddy, K. S. Krishnappa, K. Murali and Pitchaimuthu, M. 2000. Performance of French bean Varieties under Southern Dry Region of Karnataka. Karnataka J. Agric. Sci. 13(2): 503-505.

Anup Das, Subhash Babu, G.S. Yadav, M.A. Ansari, R. Singh, L.K. Baishya, D.J. Rajkhowa and Ngachan, S. V. 2016. Status and strategies for pulses production for food and nutritional security in north-eastern region of India. Indian J. Agron. 61 (Special issue): $43-$ 57.

AOAC, 1980, Official method of analysis, 13th Ed., Association of official Agricultural chemist, Washington, D.C. 2004

Beebe, S., P. Skroch, J. Tohme, M.C. Duque, F. Pedraza, and Nienhhuis, J. 2000. Structure of genetic diversity among common bean landraces of Middle American origin based on correspondence analysis of RAPD. Crop Sci. 40: 264-273. 
Broughton, W. J., G. Hernandez, M.W. Blair, S.E. Beebe, P. Gepts and Vanderleyden, J. 2003. Beans (Phaseolus spp.): model food legumes. Plant Soil. 252: 55-128

Deka, B. C., A. Thirugnanavel, R.K. Patel, A. Nath and Deshmukh, N. A. 2012. Horticultural diversity in North-East India and its improvement for value addition. Indian J. Genet. Plant Breed. 72 (2): 157-167.

Dursum, A. 2007. Variablity, heritability and co-relation studies in bean genotypes. World J. Agri. Sci. 3:12-16.

Fageria, N.K., V. C. Baligar, A. Moreira, and Portes, T. A. 2010. Dry bean genotypes evaluation for growth, yield components and phosphorus use efficiency. J. Plant Nutr. 33: 2167-2181

Guzmán-Maldonado, S.H., J. AcostaGallegos, and O. Paredes-López. 2000. Protein and mineral content of a novel collection of wild and weedy common bean (Phaseolus vulgaris L.). J. Sci. Food Agric. 80:1874-1881

Jyoti Devi, Akhilesh Sharma, Yudhvir Singh, Viveka Katoch and Kumar Chand Sharma. 2015. Genetic variability and character association studies in French bean (Phaseolus vulgaris L.) under North-Western Himalayas. Legume Res. 38 (2): 149-156

Kamaluddin, A S. 2011.Variability, correlation and path analysis for seed yield and yield related traits in common beans. Indian J. Hort. 68(1): 61-65

Mario Paredes, C., V. Viviana Becerra and Juan Tay, U. 2009. Inorganic nutritional composition of common bean (Phaseolus vulgaris L.) genotypes race Chile. Chil. J. Agric. Res. 69(4):486495.

Moraghan, J.T., and Grafton, K.F. 1997. Accumulation of $\mathrm{Ca}$ in bean cultivars differing in seed size. J. Sci. Food Agric. 74:251-256

Sheoran, O.P., D.S. Tonk, L.S. Kaushik, R.C. Hasija and Pannu, R.S. 1998. Statistical Software Package for Agricultural Research Workers. Recent Advances in information theory, Statistics \& Computer Applications by D.S. Hooda and R.C. Hasija Department of Mathematics Statistics, CCS HAU, Hisar (139-143).

Sofi, P. A., M.Y. Zargar, D. Debouck and Graner, A. 2011. Evaluation of Common Bean (Phaseolus vulgaris L) Germplasm under Temperate Conditions of Kashmir Valley. J. Phytol. 3(8): 47-52.

Verma, V. K., A. K. Jha, Avinash Pandey, Amit Kumar, P. Choudhury and Tanya L. Swer. 2014. Genetic divergence, path coefficient and cluster analysis of French bean (Phaseolus vulgaris) genotypes. Indian J. Agric. Sci. 84 (8): 925-30

\section{How to cite this article:}

Thirugnanavel, A., Bidyut C. Deka, Rakesh Kumar, Lily Rangnamei, Megokhona Meyase and Kollam Rabi. 2018. Evaluation of Rajma Bean Landraces for Growth, Yield and Quality under Low Altitude Condition of Nagaland. Int.J.Curr.Microbiol.App.Sci. 7(10): 2641-2648. doi: https://doi.org/10.20546/ijcmas.2018.710.307 